\title{
SPECIES RICHNESS AND BIOMASS RELATIONSHIP IN BURNED SITES OF Imperata-Saccharum GRASSLAND IN SUKLAPHANTA WILDLIFE RESERVE, NEPAL
}

\author{
Pitamber Pant and Hari Datt Lekhak \\ Central Department of Botany \\ Tribhuvan University, Kirtipur, Kathmandu, Nepal
}

\begin{abstract}
Present study was conducted in the Suklaphanta Wildlife Reserve, Kanchanpur district, far western Nepal during June-July, 2005. A total of 150 quadrats $(1 \mathrm{~m} \mathrm{x} 1 \mathrm{~m})$ were sampled in three differentially treated sites (unburned, early burned and late burned). Plant community composition and above ground biomass at different sites were quantified. The relationship between species richness and biomass was detected in the Imperata-Saccharum grassland. Altogether 100 plant species were recorded in the grassland. The highest number of species (62) was recorded in early burned site, whereas lowest (54) species were recorded from unburned site. Among all species recorded, 23 were common to all sites. The highest species richness $\left(13 \mathrm{species} / \mathrm{m}^{2}\right)$ was recorded in the early burned plot. The above ground biomass was highest $\left(583.93 \mathrm{~g} / \mathrm{m}^{2}\right)$ in unburned plot. Mean above ground biomass of all the three sites of the grassland was $249.72 \mathrm{~g} / \mathrm{m}^{2}$. These results indicate that the burning has significant impact on both species richness and biomass. Maximum species richness was found in the biomass interval between ca. $100-300 \mathrm{~g} / \mathrm{m}^{2}$ when all the sites were combined. A hump shaped pattern was observed in the grassland when all the data were combined.
\end{abstract}

Key words: Species richness, biomass, generalized linear model, fire.

\section{INTRODUCTION}

The link between species diversity and primary productivity continues to be a fundamental challenge for the ecological research (Loreau et al. 2001). Therefore, the relationship is emerging as a central theme in diversity studies and is fundamental to the management and conservation of biodiversity (Mittelbach et al. 2001). This relationship appears hump-shaped (unimodal) in many systems but it remains controversial till now. Decline of species richness at high biomass level is unsolved puzzle (Bhattarai et al. 2004). Cornwell and Grubb (2003) concluded that as ecology is a science of 'contingent generalizations', studies in varied biomes must continue to refine where, at what scales, and for which taxa the hump-shaped model is applicable.

The present study aims to test relationship between species richness and biomass in the grassland of Suklaphanta Wildlife Reserve.

\section{MATERIALS AND METHODS}

The $61.84 \mathrm{sq} \mathrm{km}$ study area (Suklaphanta grassland) is located inside the Suklaphanta 
Wildlife Reserve, Kanchanpur district, far western Nepal. It has tropical monsoon climate with subtropical type of vegetation. The reserve lies between the latitudes $28.49^{\circ}-28.57^{\circ} \mathrm{N}$; and longitudes $80.07^{\circ}-80.15^{\circ} \mathrm{E}$. The temperature during pre-monsoon ranges from $30^{\circ}$ to $32^{\circ} \mathrm{C}$ reaching as high as $42^{\circ} \mathrm{C}$ whereas it is $10^{\circ}$ to $12^{\circ} \mathrm{C}$ reaching upto $25^{\circ} \mathrm{C}$ during winter. The rainfall is highest during monsoon, ranges from $300 \mathrm{~mm}$ to $700 \mathrm{~mm}$. The average rainfall during winter season ranges from $20 \mathrm{~mm}$ to $50 \mathrm{~mm}$ (Chaudhary 1998).

Three sites (unburned, early burned and late burned) were selected according to biannual burning made by reserve staffs for the management and preservation of the grassland. Early burned plot was burned in the month of January whereas late burned plot was burned in April. In each site, 50 quadrates $(1 \mathrm{~m} \times 1 \mathrm{~m})$ were laid to obtain species richness and biomass separately. Species richness was determined by recording all the plant species present inside the $1 \mathrm{~m}^{2}$ plots and biomass was estimated by harvest method.

Numerical analysis was done by using S-plus and SPSS for regression and ANOVA, respectively. Generalized linear models were used to elucidate the relationship between species richness and biomass (Bhattarai et al. 2004). Species richness was taken as response variable and biomass as the explanatory variable. Frequency and relative frequency was calculated by following Zobel et al. (1987).

\section{RESULTS}

A total number of 100 plant species were recorded in the Suklaphanta. Among the sites, early burned site has highest number of plant species and the unburned site has lowest number of plant species (Table 1). Twenty three plant species were found common to all sites. The variation in species number within site as well as among sites was statistically significant. The range of frequency of different species in the grassland varied from 0.66 to $90 \%$. Imperata cylindrica was found as the most frequent and Saccharum spontaneum second most frequent species.

A mean biomass of the grassland was recorded as $249.72 \mathrm{~g} / \mathrm{m}^{2}$. The unburned site has highest mean biomass and the late burned site has lowest mean biomass. The variation in biomass was highly significant between sites but non-significant within site. The dominant species were found as the major contributors of the biomass. Litter contributed only $21.47 \%$ of the total biomass.

Mean species richness of the grassland was found as 7.47 species $/ \mathrm{m}^{2}$. The highest species richness was recorded in early burned site whereas lowest in the unburned site. Similarly, mean biomass was recorded as $249.71 \mathrm{~g} / \mathrm{m}^{2}$. The highest mean biomass was recorded in the unburned site whereas lowest in the late burned site. The range of species richness was found between 4 and 14 species $/ \mathrm{m}^{2}$ in the grassland whereas the range of biomass was found between 23 and $598 \mathrm{~g} / \mathrm{m}^{2}$. The response in species richness to biomass was different in three sites and combined site. There was no relationship between species richness and biomass when all sites were analyzed separately. However, statistically significant unimodal relationship was found when the sites were combined. Maximum species richness was found in the biomass between 100 and $300 \mathrm{~g} / \mathrm{m}^{2}$ when all sites were combined.

\section{DISCUSSION}

A total number of 100 species were recorded in the grassland which is lower than Poudyal (2000), i.e., 119 species. This is due to high temperature and low precipitation during study period. Among 100 plant species 23 plant species were common to all sites. It is found that total number of species were increased as quadrats were combined. This was one of the effect of area on species richness. Unburned site has lowest species 
richness $\left(5.96\right.$ species $\left./ \mathrm{m}^{2}\right)$ but highest biomass $\left(440.95 \mathrm{~g} / \mathrm{m}^{2}\right)$. Early burned site has highest species richness $\left(8.7\right.$ species $\left./ \mathrm{m}^{2}\right)$, however, lowest biomass is seen in the late burned site (54.78 $\mathrm{g} / \mathrm{m}^{2}$ ). The variation in above ground biomass is due to the biannual burning practice in the grassland which is reasonable. The reason behind variation in species richness and composition was due to the impact of burning and may also be the impact of grazing. The low species richness in unburned plots is due to increasing dominance of competitive species. The highest number of species in early burned site may be due to mild grazing. High frequency of Imparata and Saccharum was due to better adaptation of these species in such environment.

Table 1. Species richness (species $\left./ \mathrm{m}^{2}\right)$ and biomass $\left(\mathrm{g} / \mathrm{m}^{2}\right)$ at different sites in Suklaphanta Wildlife Reserve.

\begin{tabular}{llcccc}
\hline Plot & Variables & Maximum & Minimum & Mean & $\begin{array}{c}\text { Standard } \\
\text { deviation }\end{array}$ \\
\hline Unburned & Species richness & 9 & 4 & 5.96 & 1.21 \\
& Biomass & 583.93 & 180.06 & 440.95 & 86.00 \\
Early-Burned & Species richness & 13 & 5 & 8.7 & 2.18 \\
& Biomass & 598.00 & 40.88 & 253.42 & 147.00 \\
Late-Burned & Species richness & 14 & 5 & 7.47 & 1.90 \\
& Biomass & 146.45 & 22.83 & 54.78 & 25.92 \\
Combined & Species richness & 14 & 4 & 7.47 & 2.132 \\
& Biomass & 598.00 & 22.83 & 249.721 & 186.534 \\
\hline
\end{tabular}

Table 2. ANOVA of species richness and biomass.

\begin{tabular}{llccccc}
\hline Variables & & Sum of squares & d.f. & Mean square & F & Sig. \\
\hline Species richness & Between groups & 193.85 & 2 & 96.92 & 29.46 & .000 \\
& Within groups & 483.54 & 147 & 3.28 & 188.34 & .000 \\
& Total & 677.39 & 149 & & & \\
Biomass & Between groups & 3729156 & 2 & 1864577.76 & 188.34 & .000 \\
& Within groups & 1455303 & 147 & 9900.02 & & \\
& Total & 5184459 & 149 & & & \\
\hline
\end{tabular}

Table 3. Summary statistics of generalized linear model (GLM)*.

\begin{tabular}{|c|c|c|c|c|c|c|}
\hline Sites & Variables & d.f. & $\begin{array}{c}\text { Explained } \\
\text { deviance }\end{array}$ & $\begin{array}{l}\text { Residual } \\
\text { deviance }\end{array}$ & F-value & $\begin{array}{c}P- \\
\text { value }\end{array}$ \\
\hline \multirow[t]{3}{*}{ Early burned } & Null & 49 & & 26.22 & & \\
\hline & Biomass & 48 & 1.94 & 25.71 & 0.94 & n.s. \\
\hline & (Biomass)2 & 47 & 8.19 & 24.07 & 2.09 & n.s. \\
\hline \multirow[t]{3}{*}{ Unburned } & Null & 49 & & 11.64 & & \\
\hline & Biomass & 48 & 1.03 & 11.52 & 0.47 & n.s. \\
\hline & (Biomass)2 & 47 & 2.49 & 11.35 & 0.56 & n.s. \\
\hline \multirow[t]{4}{*}{ Late burned } & Null & 49 & & 22.071 & & \\
\hline & Biomass & 48 & 9.37 & 20.00 & 4.90 & 0.031 \\
\hline & (Biomass)2 & 47 & 53.28 & 10.31 & 1.50 & n.s. \\
\hline & Null & 149 & & 86.51 & & \\
\hline \multirow[t]{2}{*}{ Combined } & Biomass & 148 & 6.41 & 80.96 & 9.55 & 0.002 \\
\hline & $\left(^{\text {Biomass })^{2}}\right.$ & 147 & 13.03 & 75.23 & 10.69 & 0.001 \\
\hline
\end{tabular}

* Number of plant species per square meter are regressed against a linear and quadratic term of biomass in different sites (UB, LB and EB). d.f.- degree of freedom, Response variable: Species richness, Explanatory variable: Biomass 
Biomass was also influenced due to burning and dry season. Among the burned sites high mean biomass is found in early burned site because of good duration of burning at the study time. Low mean biomass in late burned site was due to late burning and may be high grazing pressure.

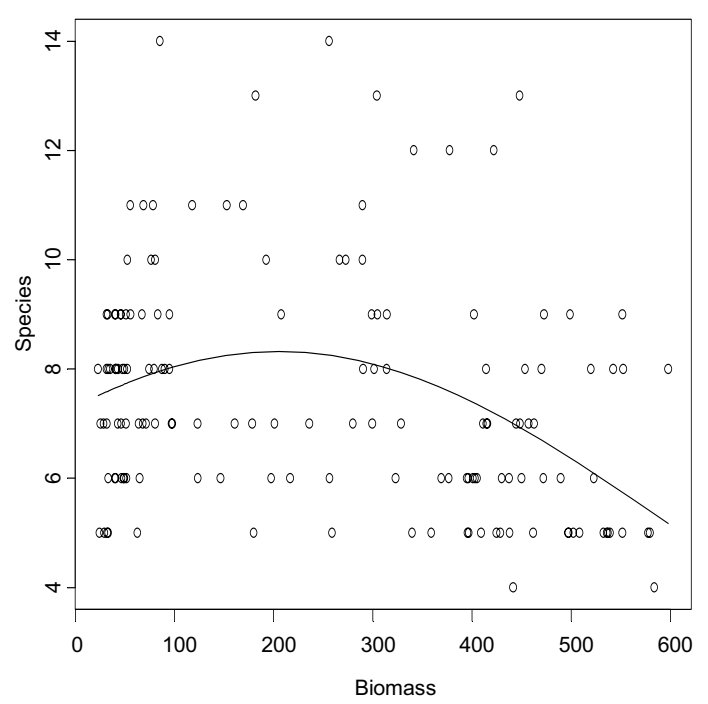

Fig. 1. The relationship between species richness and biomass in Suklaphanta grassland. The fitted line is based on a second order polynomial regression with generalized linear model.

Non significant relationship between species richness and biomass at different sites when analyzed separately was due to the lower number of quadrates. Espinar (2006) concluded that in order to identify a significant hump-shaped pattern in the data set, we must consider the results of the bootstrap procedure. Hump-shaped relationship was obtained when all the data were combined proved the model developed by Grime (1973, 1977). This result also agrees with many studies like Bhattarai et al. (2004), Espinar (2006), etc. The reason behind it is that more energy or resources can support more individuals leading to a greater number of species, or very few species were adapted to survive the difficult conditions that underlie low community biomass.

In conclusion, variations in species composition and biomass reveals that the burning has significant impact over the grassland. It is concluded that the burning is necessary to have a species rich grassland and the time of burning is also suitable. This study provides evidence of a hump-shaped pattern between species richness and biomass across the grassland.

\section{ACKNOWLEDGEMENTS}

Authors are thankful to WWF-Nepal and Cornell-Nepal study programme for financial support. Thanks are also to Mr. Tikaram Adhikari, Chief warden SWR and Dr. K.R. Bhattarai for technical support. First author (PP) is thankful to Prof. P.K. Jha for encouragement.

\section{REFERENCES}

Bhattarai, K.R., O.R. Vetaas and J.A. Grytnes. 2004. Relationship between plant species richness and biomass in an arid sub-alpine grassland of the central Himalayas, Nepal. Folia Geobotanica 39:57-71.

Chaudhary, R.P. 1998. Biodiversity in Nepal. Status and Conservation. Tec. Press Books, Bangkok.

Cornwell, W.K. and P.J. Grubb. 2003. Regional and local patterns in plant species richness with respect to resource availability. Oikos 100:417-428.

Espinar, J.L. 2006. Sample size and the detection of a hump-shaped relationship between biomass and species richness in mediterranean wetlands. Journal of Vegetation Science 17:227-232. 
Grime, J.P. 1973. Control of species richness in herbaceous vegetation. J. Environ. Management 1:151-167.

Grime, J.P. 1997. The humped-back model: A response to Oksanen. Journal of Ecology 85(1):97-98.

Loreau, M., S. Naeem, P. Inchausti, J. Bengtsson, J.P. Grime, A. Hector, D.U. Hooper, M.A. Huston, D. Raffaelli, B. Schmid, D. Tilman and D.A. Wardle. 2001. Ecology: Biodiversity and ecosystem functioning: Current knowledge and future challenges. Science 294:804-808.

Mittelbach, G., C.F. Steiner, S.M. Scheiner, K.L. Gross, H.L. Reynolds, R.B. Waide, M.R.
Willing, S.I. Dodson and L. Gough. 2001. What is the observed relationship between species richness and productivity? Ecology 82(9):2381-2396.

Poudyal, S. 2000. Impact of management practices on species composition and soil characteristics in grasslands of Royal Suklaphanta Wildlife Reserve, Nepal. M.Sc. Thesis, Central Department of Botany, Tribhuvan University, Kirtipur, Kathmandu.

Zobel, D.B., P.K. Jha, M. Behan and U.K.R. Yadav. 1987. A Practical Manual for Ecology. Ratna Book Distributors, Kathamandu, Nepal. 